\title{
SISTEM PENDUKUNG KEPUTUSAN PENENTUAN SISWA TELADAN MENGGUNAKAN METODE SIMPLE ADDITIVE WEIGHTING (SAW) STUDI KASUS : SD BHAKTI YKKP
}

\author{
Galih Surono $^{1 *}$, Nur Nawaningtyas Pusparini ${ }^{2}$ \\ 1,2 Program Studi Teknik Informatika STMIK Widuri Jakarta, Indonesia \\ E-mail: ${ }^{1}$ galihsurono@kampuswiduri.ac.id , ${ }^{2}$ tyaspusparini@ kampuswiduri.ac.id
}

Submission date: 2020-06-04

Accepted date: 2020-06-09

\begin{abstract}
Exemplary students are students of noble and accomplished character. Exemplary student assessments in schools are essential to motivate students to be better. Sekolah Bhakti YKKP is a school that plans to conduct an exemplary student assessment. The exemplary student assessment in SD Bhakti is taken from 8 aspects of assessment, namely: Average player ratings value, moral, discipline, attendance, point of offense, extracurricular activities of the race and book lover. A lot of data and different judging aspects become constraints in the assessment process, to solve this problem. The purpose of this research is to create a decision support system (SPK) as a solution to help schools in determining exemplary students. SPK applied is using Simple Additive Weighting (SAW) method, because this method can calculate various values based on predefined criteria and weights. After the calculation process is complete, the calculation result of the SAW method can be used to determine the student model based on the best class rating. Based on the results of the test using the PHP programming language and two methods of testing Black Box with an average percentage of $86 \%$ and testing Delone and McLean Model with an average percentage of $88 \%$.
\end{abstract}

Keywords: SPK, SAW, Exemplary students, Delone, McLean

\begin{abstract}
ABSTRAK
Siswa teladan adalah siswa yang karakter mulia dan berprestasi. Penilaian siswa teladan di sekolah sangat penting untuk memotivasi siswa untuk menjadi lebih baik. SD Bhakti YKKP adalah sekolah yang berencana untuk melakukan penilaian siswa teladan. Penilaian siswa teladan di SD Bhakti diambil dari 8 aspek penilaian, yaitu: nilai rapor rata-rata, moral, disiplin, absensi, poin pelanggaran, kegiatan ekstrakurikuler lomba dan book lover. Permasalahan dalam penelitian ini adalah jumlah data yang banyak dan aspek penilaian yang berbeda menjadi kendala dalam proses penilaian. Tujuan dari penelitian ini adalah untuk membuat sebuah Sistem Pendukung Keputusan (SPK) sebagai solusi untuk membantu sekolah dalam menentukan siswa teladan. SPK yang diterapkan adalah menggunakan metode Simple Additive Weighting (SAW), karena metode ini dapat menghitung berbagai nilai berdasarkan kriteria dan bobot yang telah ditentukan. Setelah proses perhitungan selesai, hasil perhitungan metode SAW dapat digunakan untuk menentukan model siswa berdasarkan pada peringkat kelas terbaik. Berdasarkan hasil pengujian menggunakan bahasa pemrograman PHP dan dua metode yaitu Pengujian Black Box dengan persentase rata-rata $86 \%$ dan pengujian Delone and McLean Model dengan persentase rata-rata $88 \%$.
\end{abstract}

Kata Kunci: SPK, SAW, Siswa teladan, Delone, McLean

\section{PENDAHULUAN}

SD Bhakti YKKP merupakan sekolah dasar swasta yang berstandar nasional yang terletak di Jakarta Utara. Jumlah siswa sebanyak 718 anak, yang terbagi menjadi 26 kelas. SD Bhakti YKKP turut berperan serta mendidik generasi bangsa, untuk menjadi pribadi yang bertaqwa, cinta dan bangga terhadap bangsa dan negara, dan dapat menjadi contoh bagi generasi-generasi selanjutnya. Sebagai wujud bentuk partisipasi dalam mendidik siswa menjadi generasi unggulan, Pihak sekolah mempunyai program tahunan.
Program yang diterapkan adalah pemilihan siswa teladan. Siswa teladan merupakan siswa berprestasi dan berakhlak mulia. Penilaian siswa teladan dalam sebuah sekolah sangat penting untuk memotivasi para siswa menjadi lebih baik. SD Bhakti YKKP merupakan sekolah yang berencana menerapkan sistem penilaian siswa teladan. Penerapan sistem penilaian siswa teladan di SD Bhakti YKKP dilakukan dengan cara menggabungkan kriteria dari program penilaian siswa berpresatasi akademik dan nonakademik, yaitu: Kedisiplinan, Akhlak, nilai raport, book lover, 
absensi, point pelanggaran, nilai ekstrakurikuler, dan lomba.

Permasalahan pada penelitian ini adalah penggabungan nilai kriteria pihak sekolah mengalami kendala, karena jumlah data yang diolah banyak dan terkadang terjadi human error. Metode Simple Additive Weighting (SAW) merupakan salah satu metode yang digunakan dalam sistem pendukung keputusan. Metode SAW banyak digunakan dalam penelitian untuk menyelesaikan suatu permasalahan.

Tujuan dari penelitian ini adalah untuk membuat sebuah Sistem Pendukung Keputusan (SPK) sebagai solusi untuk membantu sekolah dalam menentukan siswa teladan. SPK yang diterapkan adalah menggunakan metode Simple Additive Weighting (SAW), karena metode ini dapat menghitung berbagai nilai berdasarkan kriteria dan bobot yang telah ditentukan (Pusparini et al., 2020).

Seperti penelitian yang dilakukan Agus Faizin dan Edy Mulyanto, melakukan penelitian tentang penerapan metode SAW untuk seleksi tenaga kerja baru bagian produksi (studi kasus pada PT. Jesi Jason Surja Wibowo), membahas tentang bagaimana mendapatkan tenaga kerja yang ideal berdasarkan 4 kriteria. Hasil akhir dari penelitiannya adalah mendapatkan calon tenaga kerja yang ideal dengan nilai tertinggi (Faizin \& Mulyanto, 2015).

Penelitian tentang siswa teladan dilakukan oleh Halim Agung dan Ricky dengan judul Aplikasi Sistem Pendukung Keputusan Untuk Pemilihan Siswa Teladan Menggunakan Metode Topsis, Hasil akhir yang diperoleh dari penelitiannya adalah aplikasi desktop yang dapat membantu proses pemilihan siswa teladan berdasarkan data nilai akademis dan nilai kepribadian siswa (Agung \& Ricky, 2016).

\section{METODE PENELITIAN}

Metodologi penelitian diperlukan sebagai panduan proses penelitian, sehingga proses penelitian dapat dilakukan secara sistematis. Metodologi penelitian ini adalah sebagai berikut:

Dalam penelitian diperlukan suatu teknik atau cara mencari, memperoleh, mengumpulkan dan mencatat data. Kebenaran data yang diperoleh berhubungan dengan pokok permasalahan dalam penelitian. Untuk mengetahui bagaimana seharusnya penelitian dilakukan yaitu dengan menggunakan metode penelitian. Metode penelitian pada dasarnya merupakan cara ilmiah untuk mendapatkan data dengan tujuan dan kegunaan tertentu (Sukardi, 2004)

Jenis penelitian yang dilakukan di SD bhakti YKKP adalah penelitian kuantitatif, untuk mendapatkan gambaran yang lebih lengkap dari objek yang diteliti dengan melakukan wawancara langsung dengan pihak sekolah bagian kesiswaan.
Hasil dari wawancara diperoleh informasi dan masalah yang berkaitan dengan siswa teladan, beserta usulan alternatif pemecahan masalah yang ada (Budiyantara et al., 2020).

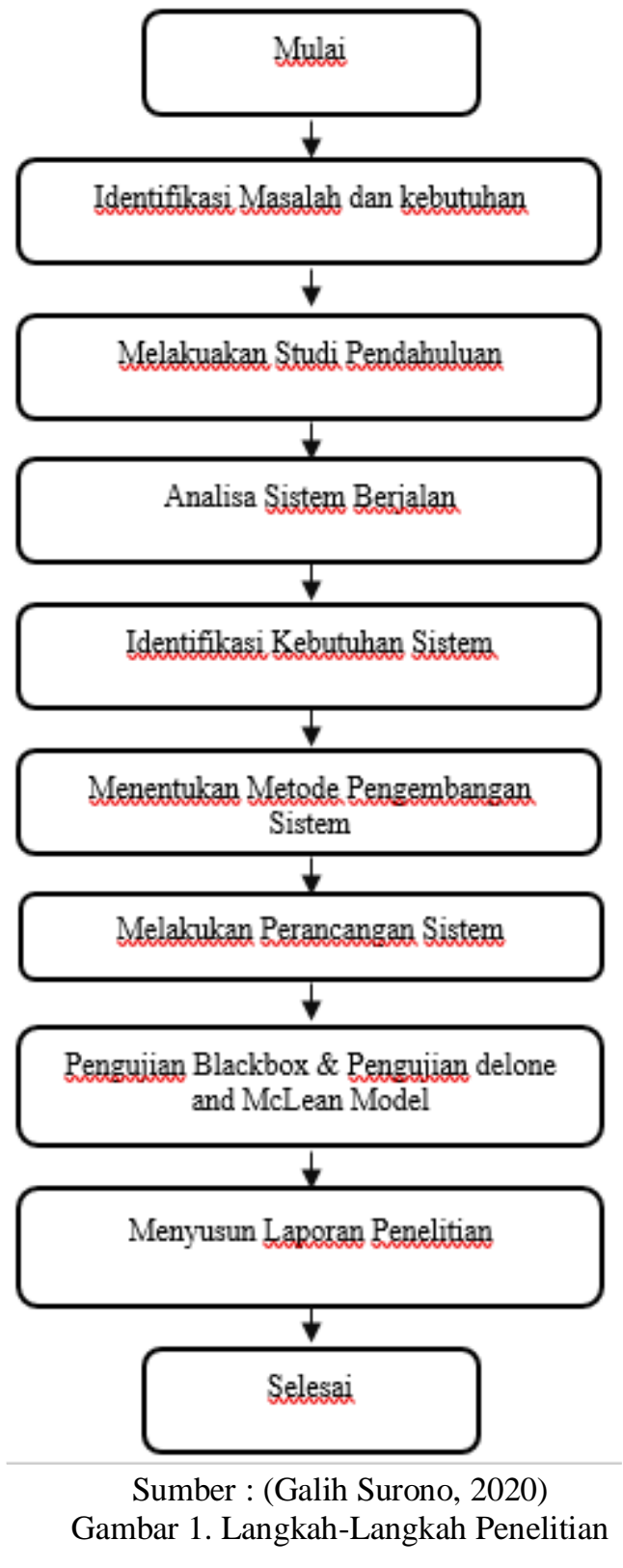

Langkah - langkah untuk melakukan penelitian yaitu:

1. Langkah pertama dalam penelitian ini diawali dengan melakukan identifikasi masalah. Langkah ini akan menghasilkan rumusan masalah

2. Setelah masalah di rumuskan kemudian dilakukan tinjauan penelitian mulai dari tinjauan pustaka, tinjauan studi dan tinjuan objek penelitian, langkah ini dilakukan untuk mencari cara terbaik untuk menyelesaikan rumusan masalah.

3. Langkah selanjutnya dibuat suatu metodologi untuk penyelesaian masalah, mulai dari metode 
penelitian, metode pengumpulan data, metode pemilihan sample dan instrumentasi.

4. Setelah metodologi dilakukan, kemudian melakukan perancangan sebuah model yang akan dibuat menggunakan UML hal ini di lakukan untuk mempermudah pembuatan model yang sesungguhnya.

5. Kemudian berdasarkan dari hasil analisa dan perancangan dibuat sebuah model pendukung keputusan untuk menentukan siswa teladan di SD Bhakti YKKP dengan metode SAW.

6. Model yang telah dibuat akan dilakukan suatu pengujian validitas Blackbox dan pengujian kualitas model dengan mengadopsi Delon Mclean model yaitu :Information Quality, System Quality, Service Quality, Use, dan User Satisfaction.

7. Langkah terakhir membuat laporan hasil penelitian yang telah dilakukan.

\section{HASIL DAN PEMBAHASAN}

\section{Pengumpulan Data}

Langkah Awal yang dilakukan adalah membahas proses pengumpulan data. Penentuan Alternatif dan kriteria sistem pendukung keputusan penentuan siswa teladan SD Bhakti YKKP dan mengidentifikasi data yang terkumpul dari hasil wawancara dan kuisioner (Sani, 2018).

\section{Analisis Pembahasan Masalah}

Dalam Penelitian ini membahas hasil analisa perhitungan metode SAW untuk pembobotan dan perangkingan, sehingga diketahui kelayakan dari masing-masing siswa, yang akan terpilih menjadi siswa teladan di SD Bhakti YKKP. Dalam menentukan bobot preferensi akan dilakukan tiga sekenario pembobotan yang berbeda untuk mengetahui pengaruh dari nilai bobot preferensi terhadap hasil akhir perangkingan. Dalam pembahasan ini akan digunakan 4 siswa sebagai Alternatif dari jumlah siswa siswa yang sebenarnya adalah 718 siswa. Hal ini dilakukan untuk mempermudah peoses dokumentasi.

\section{Perancangan Sistem}

Pada tahap perancangan sistem ini akan dibuat sebuah aplikasi berbasis web menggunakan bahasa pemprograman PHP dan XAMPP Sebagai databasenya (Goldie Gunadi, 2019).

\section{Use Case Diagram}

Tahap perancangan sistem siswa teladan dilakukan beberapa langkah yang pertama membuat usecase diagram

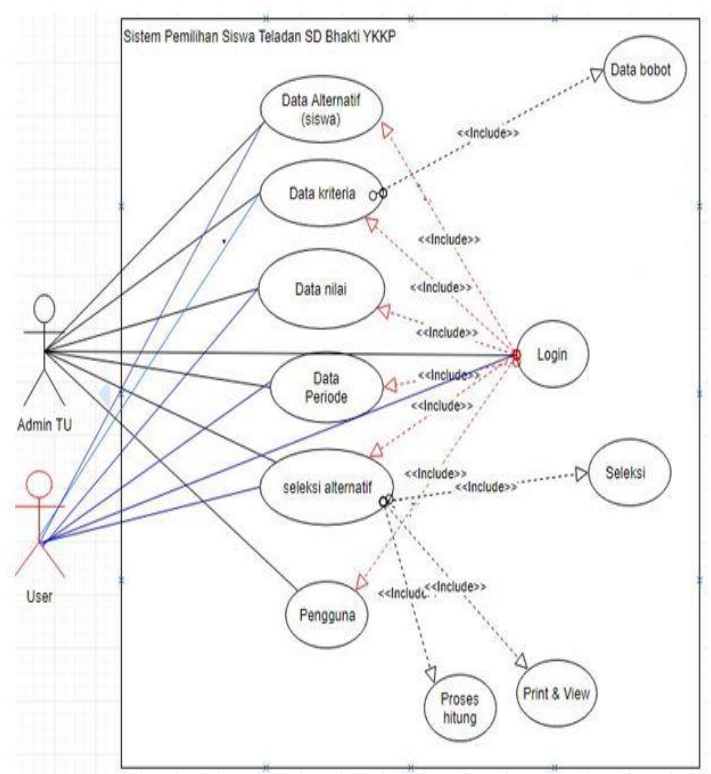

Sumber : (Galih Surono, 2020)

Gambar 2. Use Case Diagram siswa teladan

\section{Squence diagram}

Squence diagram ini menggambarkan kolaborasi dinamis antara object yang menunjukan rangkaian pesan antara aktor dan sistem. Berikut adalah Squence diagram Sistem pendukung keputusan pemilihan siswa teladan SD Bhakti YKKP.

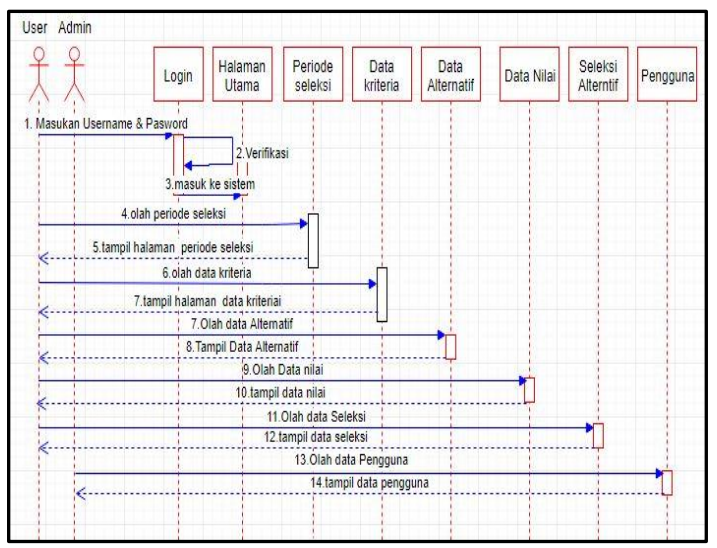

Sumber : (Galih Surono, 2020)

Gambar 3. Squence diagram pemilihan siswa teladan

\section{Class Diagram}

Class diagram sistem pendukung keputusan penentuan siswa teladan, pada penelitian ini menggambarkan struktur dan diskripsi class serta hubungan antar class, seperti gambar dibawah ini. 


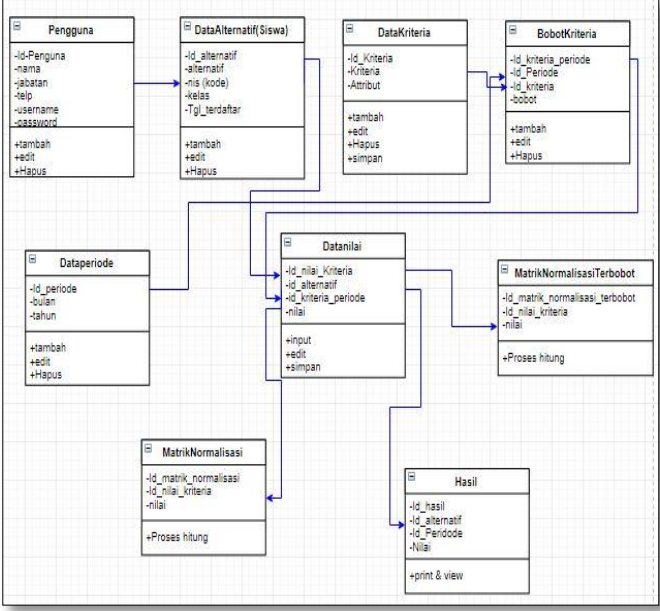

Sumber : (Galih Surono, 2020)

Gambar 4. Class diagram pemilihan siswa teladan

\section{Analisis Langkah-Langkah Metode SAW}

Langkah - langkah pada metode SAW yaitu sebagai berikut :

1) Menentukan alternatif, yaitu Ai.

2) Menentukan kriteria yang akan dijadiakan acuan dalam pengambilan keputusan, yaitu $\mathrm{Cj}$.

3) Menentukan bobot preferensi atau tingkat kepentingan (W) dari setiap kriteria. $\mathrm{W}=[\mathrm{W} 1 \mathrm{~W} 2 \mathrm{~W} 3 \ldots \mathrm{Wj}]$

4) Membuat tabel rating kecocokan setiap alternatif pada setiap kriteria.

5) Membuat matrik keputusan $X$ yang di bentuk dari tabel rating kecocokan dari setiap alternatif pada setiap kriteria. Nilai $\{\mathrm{x}\}$ setiap alternatif (Ai) pada setiap kriteria $(\mathrm{Cj})$ yang sudah ditentukan dimana, $i=1,2, . . m$ dan $\mathrm{j}=1,2, . . \mathrm{n}$.

6) Melakukan noramalisasi matrik keputusan $\mathrm{X}$ dengan cara menghitung nilai rating kinerja ternormalisasi (Rij) dari alternatif (Ai) pada kriteria $(\mathrm{Cj})$.

7) Hasil dari nilai rating kinerja ternormalisasi (Rij) membentuk matrik ternoralisasi (R)

8) Hasil akhir nilai preferensi (Vi) diperoleh dari penjumlahan dari perkalian elmen baris matrik ternormalisasi (R) dengan bobot preferensi (W) yang bersesuaian elemen kolom matrik (W).

Analisis Pemecahan Masalah menggunakan metode Simple Additive Weighting (SAW)

1) Menentukan alternatif, alternatif dalam penelitian ini adalah siswa-siswi SD Bhakti YKKP dalam jurnal ini penulis akan menggunakan 4 siswa alternatif penilaian.
Tabel 1. Alternatif

$\frac{\frac{\frac{\text { Nama Alternatif }}{\text { Raynaldy }}}{\text { Zhafif }}}{\text { Nanda }}$

2) Kriteria siswa teladan

Tabel 2. Kriteria

\begin{tabular}{cl}
\hline Kriteria (C) & \multicolumn{1}{c}{ Keterangan } \\
\hline C1 & Ekstrakurikuler $(\mathrm{EK})$ \\
\hline $\mathrm{C} 2$ & Lomba (L) \\
\hline C3 & Book Lover $(\mathrm{BL})$ \\
\hline C4 & Point Pelanggaran $(\mathrm{PP})$ \\
\hline C5 & Kehadiran $(\mathrm{KH})$ \\
\hline C6 & Kedisiplinan $(\mathrm{KD})$ \\
\hline C7 & Akhlak $(\mathrm{AK})$ \\
\hline C8 & Nilai Rapot $(\mathrm{NR})$ \\
\hline Sumber : (Galih Surono, 2020)
\end{tabular}

3) Nilai Bobot kriteria

Tabel.3 Bobot kriteria

\begin{tabular}{cc}
\hline Nilai bobot Kriteria & Keterangan \\
\hline 1 & Sangat buruk \\
\hline 2 & Buruk \\
\hline 3 & Cukup \\
\hline 4 & Baik \\
\hline 5 & Sangat baik \\
\hline
\end{tabular}

Sumber : (Galih Surono, 2020)

Tabel 4. Bobot kriteria rapot

\begin{tabular}{cc}
\hline Kriteria nilai rapot & Bobot $(\mathbf{W})$ \\
\hline $90-100$ & 5 \\
\hline $80-89$ & 4 \\
\hline $70-79$ & 3 \\
\hline $60-69$ & 2 \\
\hline $50-59$ & 1 \\
\hline
\end{tabular}

Sumber : (Galih Surono, 2020)

Tabel 5. Bobot kriteria Akhlak

\begin{tabular}{cc}
\hline Kriteria Akhlak & Bobot $(\mathbf{W})$ \\
\hline $90-100$ & 5 \\
\hline $80-89$ & 4 \\
\hline $70-79$ & 3 \\
\hline $60-69$ & 2 \\
\hline $50-59$ & 1 \\
\hline Sumber : (Galih Surono, 2020)
\end{tabular}

Tabel 6. Bobot kriteria Kedisiplinan

\begin{tabular}{cc}
\hline Kriteria Kedisiplinan & Bobot $(\mathbf{W})$ \\
\hline A & 5 \\
\hline B & 4 \\
\hline C & 3 \\
\hline D & 2 \\
\hline E & 1 \\
\hline Sumber : (Galih Surono, 2020)
\end{tabular}


Tabel 7. Bobot kriteria Kehadiran

\begin{tabular}{cc}
\hline Kriteria Kehadiran & Bobot $(\mathbf{W})$ \\
\hline 0 & 5 \\
\hline 1 & 4 \\
\hline $2-3$ & 3 \\
\hline $4-5$ & 2 \\
\hline$>=6$ & 1 \\
\hline Sumber : (Galih Surono, 2020$)$
\end{tabular}

Tabel 8. Bobot kriteria Point Pelanggaran Kriteria Point Bobot (W)

Pelanggaran

\begin{tabular}{cc}
\hline $0-25$ & 5 \\
\hline $26-50$ & 4 \\
\hline $51-100$ & 3 \\
\hline $101-200$ & 2 \\
\hline$>=201$ & 1 \\
\hline Sumber $\cdot($ Galih Surono, 2020$)$
\end{tabular}

Sumber : (Galih Surono, 2020)

Tabel 9. Bobot kriteria Book Lover

\begin{tabular}{cc}
\hline Kriteria Book Lover & Bobot $(\mathbf{W})$ \\
\hline$>=100$ & 5 \\
\hline $80-99$ & 4 \\
\hline $50-79$ & 3 \\
\hline $20-49$ & 2 \\
\hline $1-19$ & 1 \\
\hline
\end{tabular}

Sumber : (Galih Surono, 2020)

Tabel 10. Bobot kriteria Lomba

\begin{tabular}{cc}
\hline Kriteria Lomba & Bobot $(\mathbf{W})$ \\
\hline Internasional & 5 \\
\hline Nasional & 4 \\
\hline Propinsi & 3 \\
\hline Kab/Kota & 2 \\
\hline Antar Kelas & 1 \\
\hline Sumber : (Galih Surono, 2020)
\end{tabular}

Tabel 11. Bobot kriteria Ektrakurikuler

\begin{tabular}{cc}
\hline Kriteria Ektrakurikuler & $\begin{array}{c}\text { Bobot } \\
(\mathbf{W})\end{array}$ \\
\hline A & 5 \\
\hline B & 4 \\
\hline C & 3 \\
\hline D & 2 \\
\hline E & 1 \\
\hline Sumber $:($ Galih Surono, 2020$)$
\end{tabular}

Sumber : (Galih Surono, 2020)

4) Bobot preferensi (bobot kepentingan)

Bobot Preferensi yang ditetapkan sekolah adalah sebagai berikut:

Tabel 12. Bobot preferensi Sekolah

\begin{tabular}{lcccccccc}
\hline Kriteria & EK & L & BL & $\begin{array}{c}\mathbf{P} \\
\mathbf{P}\end{array}$ & KH & KD & AK & NR \\
& & & & & & & \\
\hline Bobot & 1 & 2 & 2 & 3 & 3 & 3 & 4 & 5
\end{tabular}

Sumber : (Galih Surono, 2020)
5) Gambar Tabel reting kecocokan alternatif

\begin{tabular}{|c|l|c||c|c|c|c|c|c|c|c|}
\hline \multirow{2}{*}{ Nis } & \multirow{2}{*}{$\begin{array}{c}\text { Nama } \\
\text { Altematif }\end{array}$} & \multicolumn{1}{|c||}{ Kelas } & \multicolumn{7}{|c|}{ Nilai Kriteria } \\
\cline { 5 - 11 } & & EK & L & BL & PP & KH & KD & AK & NR \\
\hline \hline 5293 & Zhafif & 6C & 5 & 3 & 3 & 5 & 5 & 4 & 5 & 5 \\
\hline 88 & Raynaldy & 5BL & 5 & 1 & 3 & 2 & 3 & 5 & 4 & 5 \\
\hline 141 & Alya & 3BLB & 5 & 1 & 3 & 5 & 3 & 5 & 5 & 4 \\
\hline 4983 & Nanda & 5B & 5 & 1 & 2 & 4 & 3 & 5 & 5 & 5 \\
\hline
\end{tabular}

Sumber : (Galih Surono, 2020)

Gambar 5. Tabel Rating Kecocokan alternatif

6) Gambar Tabel Matrik Normalisasi

\begin{tabular}{|c|l|c|c|c|c|c|c|c|c|c|}
\hline \multirow{2}{*}{ Nis } & \multirow{2}{*}{$\begin{array}{c}\text { Nama } \\
\text { Altematif }\end{array}$} & \multirow{2}{*}{ Kelas } & \multicolumn{8}{|c|}{ Nilai Kriteria } \\
\cline { 5 - 10 } & & EK & L & BL & PP & KH & KD & AK & NR \\
\hline \hline 5293 & Zhafif & $6 C$ & 1,00 & 1,00 & 1,00 & 0,20 & 0,60 & 0,80 & 1,00 & 1,00 \\
\hline 88 & Raynaldy & 5BL & 1,00 & 0,33 & 1,00 & 0,50 & 1,00 & 1,00 & 0,80 & 1,00 \\
\hline 141 & Alya & 3BLB & 1,00 & 0,33 & 1,00 & 0,20 & 1,00 & 1,00 & 1,00 & 0,80 \\
\hline 4983 & Nanda & SB & 1,00 & 0,33 & 0,67 & 0,25 & 1,00 & 1,00 & 1,00 & 1,00 \\
\hline
\end{tabular}

Sumber : (Galih Surono, 2020)

Gambar 6. Tabel Matrik normalisasi

7) Hasil akhir

Pada tahap akhir akan dibuat perangkingan untuk mengetahui peringkat terbaik yang akan menjadi kandidat terpilih siswa teladan.

Tebel.13 Hasil perangkingan

\begin{tabular}{ccc}
\hline Peringkat & Nama & Nilai \\
\hline 1 & Raynaldy & 19.36667 \\
\hline 2 & Zhafif & 18.8 \\
\hline 3 & Nanda & 18.75 \\
\hline 4 & Alya & 18.26667 \\
\hline & Sumber : (Galih Surono, 2020)
\end{tabular}

Sumber : (Galih Surono, 2020)

\section{Tampilan Sistem}

1) Tampilan halaman login

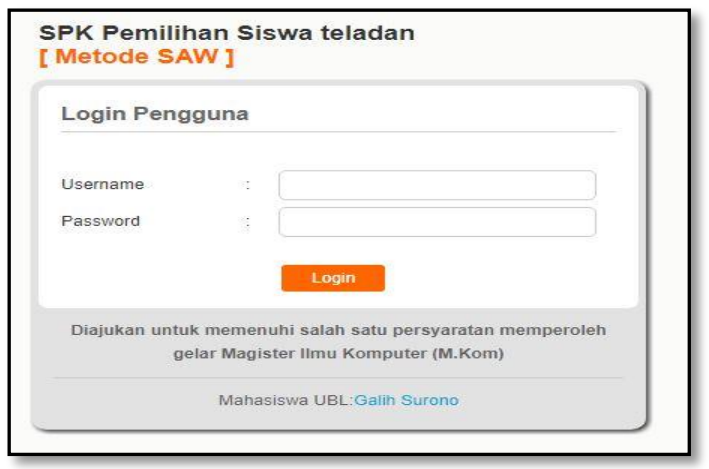

Sumber : (Galih Surono, 2020)

Gambar 7. Halaman login 
2) Tampilan halaman beranda

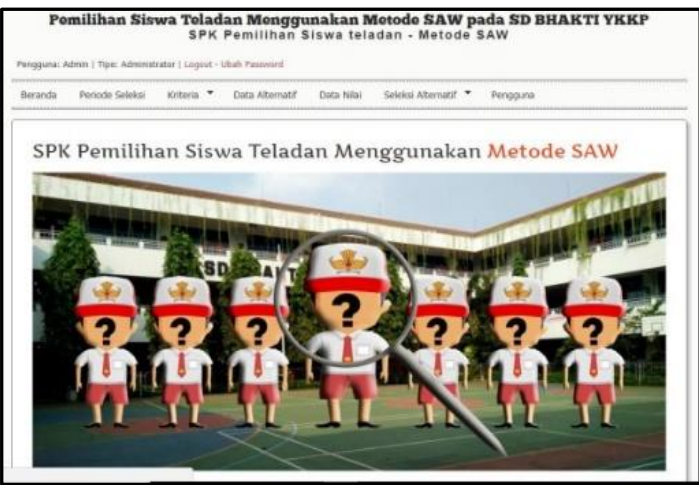

Sumber : (Galih Surono, 2020)

Gambar 8. Halaman Beranda

3) Tampilan halaman periode seleksi

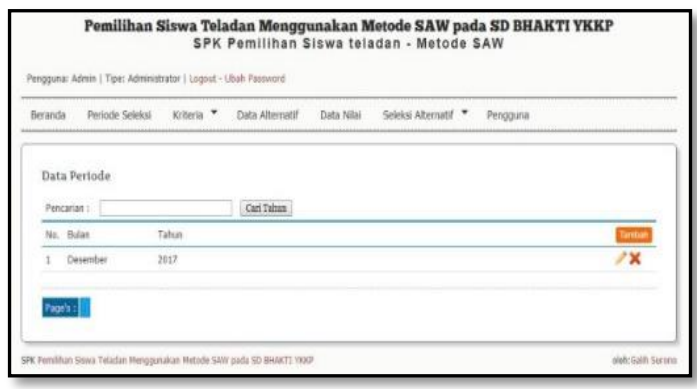

Sumber : (Galih Surono, 2020)

Gambar 9. Halaman periode Seleksi

4) Tampilan halaman data kriteria

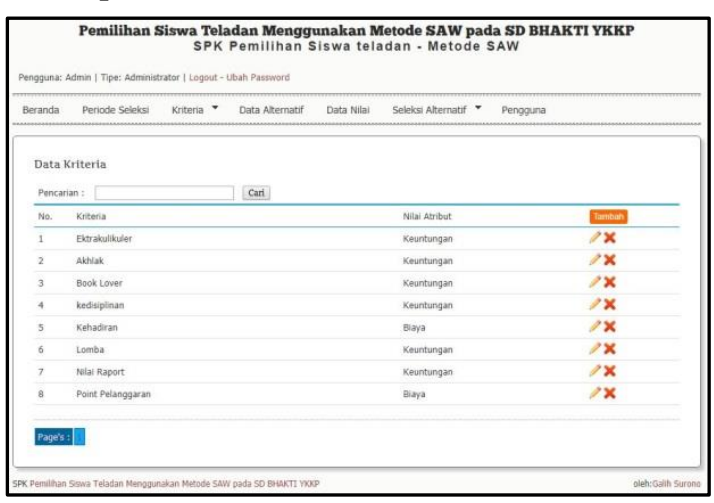

Sumber : (Galih Surono, 2020) Gambar 10. Halaman data kriteria

5) Tampilan halaman data kriteria dan bobot

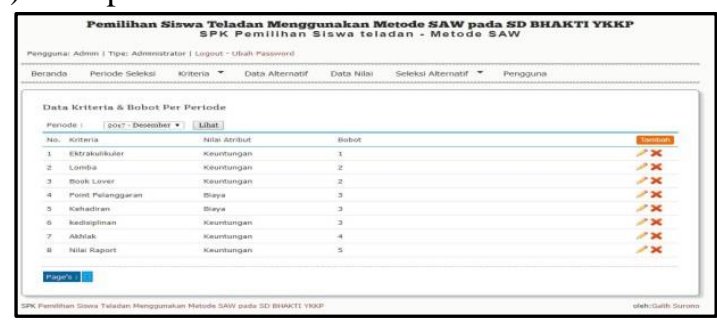

Sumber : (Galih Surono, 2020)

Gambar 11. Halaman data kriteria dan bobot
6) Tampilan halaman data alternatif (siswa)

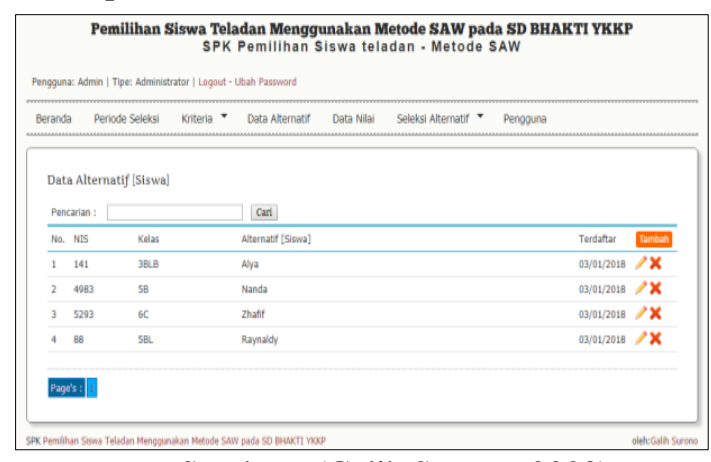

Sumber : (Galih Surono, 2020)

Gambar 12. Halaman data alternatif siswa

7) Tampilan halaman data nilai

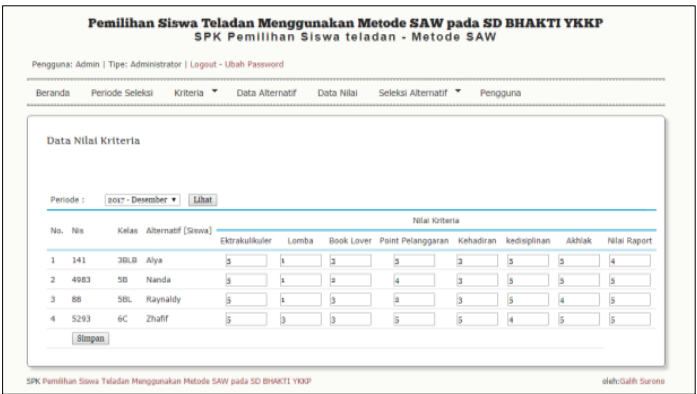

Sumber : (Galih Surono, 2020)

Gambar 13. Halaman data nilai

8) Tampilan halaman seleksi alternatif

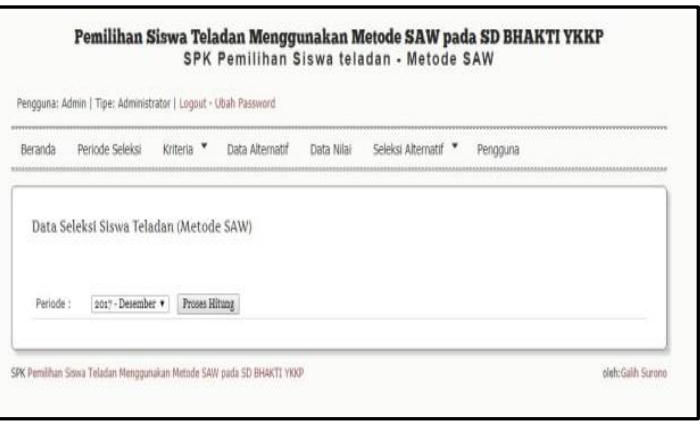

Sumber : (Galih Surono, 2020)

Gambar 14. Halaman seleksi alternatif

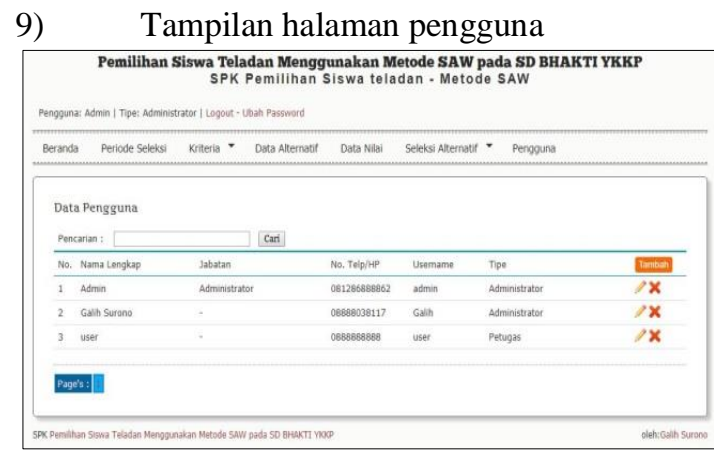

Sumber : (Galih Surono, 2020) Gambar 15. Halaman pengguna 


\section{KESIMPULAN}

Berdasarkan dari urain yang dijelaskan, maka dapat diperoleh kesimpulan sebagai berikut:

Perancangan Sistem Pendukung Keputusan penentuan siswa teladan di SD Bhakti YKKP menggunakan Metode Simple Additive Weighting, melalui pengujian black box dapat diterima, dan setelah Delon Maclean Model hasilnya sangat baik. Pembobotan nilai dapat digunakan sebagai solusi dalam mengoprasikan bentuk nilai yang mempunyai variabel yang berbeda. Dan metode saw dapat diterapkan untuk menentukan siswa teladan dengan mencari peringkat terbaik dari pembobotan kriteria yang telah ditentukan.

\section{DAFTAR PUSTAKA}

Agung, H., \& Ricky. (2016). Aplikasi Sistem Pendukung Keputusan Untuk Pemilihan Siswa Teladan Menggunakan Metode Topsis. Jurnal Ilmiah Fifo, VIII(2), 112-126. https://doi.org/10.22441/fifo.v8i2.1306
Agus Budiyantara, Irwansyah, Egi Prengki, P. A. P. (2020). Komparasi Algoritma Decision Tree, Naive Bayes Dan K-Nearest Neighbor Untuk Memprediksi Mahasiswa Lulus Tepat Waktu.

Faizin, A., \& Mulyanto, E. (2015). Penerapan Metode Simple Additive Weighting ( SAW ) Untuk Seleksi Tenaga Kerja Baru Bagian Produksi ( Studi Kasus Pada PT . Jesi Jason Surja Wibowo ). Universitas Dian Nuswantoro Semarang, 1-9.

Galih Surono, N. N. P. (2020). Sistem Pendukung Keputusan Penentuan Siswa Teladan Menggunakan Metode Simple Additive Weighting (SAW) Studi Kasus : SD BHAKTI $Y K K P$.

Goldie Gunadi. (2019). Pengembangan Aplikasi Web Berbasis Flexbox Untuk Pengelolaan Jadwal Produksi Dan Dokumen Digital Menggunakan Framework Bulma DI PT. GRAMEDIA.

Pusparini, N. N., Budiyantara, A., \& Lusa, S. (2020). Pengaruh Knowledge Management System Untuk Jenjang Jabatan. 4(1), 80-88.

Sani, A. (208). Penerapan Metode K-Means Clustering Pada Perusahaan. Jurnal Ilmiah Teknologi Informasi, 353, 1-7.

Sukardi. (004). Metodologi Penelitian Pendidikan: Kompetensi dan Praktiknya. Bumi Aksara. 
